\title{
Shrimp (Pandalopsis dispar) waste hydrolysate as a source of novel $\beta$-secretase inhibitors
}

\author{
Eunice C. Y. Li-Chan ${ }^{1}$, Imelda W. Y. Cheung ${ }^{1}$ and Hee-Guk Byun ${ }^{2 *}$
}

\begin{abstract}
In this study, purified peptides from shrimp waste hydrolysates (SWHs) were examined for their inhibitory effects against $\beta$-secretase. During consecutive purification using a Sephadex G-25 column chromatography and high performance liquid chromatography on a C18 column, a potent $\beta$-secretase inhibitory peptide Asp-Val-Leu-PheHis (629 Da) was isolated and identified from SWH24 by Q-TOF MS/MS and the $\mathrm{IC}_{50}$ value was determined to be $92.70 \mu \mathrm{M}$. The $\beta$-secretase inhibition patterns of the purified peptides were found to be competitive. Among synthesized $\beta$-secretase inhibitory peptides, Leu-Phe-His had higher $\beta$-secretase inhibitory activity than the others. The result of this study suggests that the $\beta$-secretase inhibitory peptide derived from SWH 24 could be potential candidates to develop nutraceuticals and pharmaceuticals.
\end{abstract}

Keywords: Alzheimer's disease, $\beta$-secretase inhibitory activity, Shrimp waste hydrolysates, Peptide

\section{Background}

Successful public health policies and socioeconomic development have resulted in increasing number of elderly population globally, which are accompanied by challenges to address various health issues of an aging society. The World Health Organization reported in 2012 that 35.6 million people worldwide are living with dementia or Alzheimer's disease $(\mathrm{AD})$, and that this number will triple to 115.4 million by 2050 (World Health Organization and Alzheimer's Disease International, 2012). Much of $A D$ research has been focused on the amyloid cascade hypothesis, which states that amyloid beta $(\mathrm{A} \beta)$, a proteolytic derivative of the large trans-membrane protein amyloid precursor protein (APP), plays an early and crucial role in all cases of $\mathrm{AD}$. Consequently, blocking the production of $\mathrm{A} \beta$ by specific inhibition of the $\beta$-secretase required for $A \beta$ generation is a major focus of research into AD therapy (Citron 2004). $\beta$-secretase (EC 3.4.23.46), an aspartic peptidase also known as memapsin 2 and BACE1, is the first protease that processes $A P P$ in the pathway leading to $A \beta$ production. Excessive levels of $A \beta$ in the brain are closely related to $A D$ pathogenesis, so much research has been focused on developing

\footnotetext{
* Correspondence: hgbyun@gwnu.ac.kr

${ }^{2}$ Department of Marine Biotechnology, Gangneung-Wonju National

University, Gangneung 210-702, Republic of Korea

Full list of author information is available at the end of the article
}

drugs that can inhibit $\beta$-secretase and thereby reduce $A \beta$ levels as a therapeutic treatment for AD. High-throughput screening of compound collections and natural product extracts, together with drug design building on structure-activity relationships, have led to the discovery and development of both peptide and non-peptide inhibitors of the enzyme. These include compounds such as the peptidic $\beta$-secretase inhibitor OM99-1, other aspartic protease inhibitors, an eight-residue transition state inhibitor OM99-2 (Chen et al. 1995), and a more potent eight-residue transition state inhibitor OM00-3 (Turner et al. 2001). Chitosan derivatives from crab shell exhibited weak $\beta$-secretase inhibition (Byun et al. 2005), while catechins from green tea, ellagic acid from pomegranate (Kwak et al. 2005), hispidin from mycelial cultures of Phellinus linteus (Park et al. 2004), and several compounds isolated from Sanguisorbae radix (Lee et al. 2011) have also all been studied as $\beta$-secretase inhibitors. Moreover, several hydroxyl-containing inhibitors have been reported (Cumming et al. 2004).

Shrimp have a high market value but the remaining heads and shells, which account for half of the shrimp weight, are typically removed after processing (Cheung et al. 2012). Many studies have examined the potential use of these underutilized materials, termed shrimp processing by-products, for functional properties that are applicable to industries such as pharmaceutical, functional 
food, and nutraceuticals (Dey and Dora 2014; Cheung and Li-Chan 2010).

Functional peptides can be produced from enzymatic hydrolysis of various bio-resource proteins. Bioactive peptides are usually 3-10 amino acid residue chains whose activity is based on their amino acid composition and sequence (Stachel et al. 2004), and whose functions include regulatory effects related to nutrient uptake, immune defense (Chen et al. 1995), and antioxidant activity (Mendis et al. 2005). Moreover, some peptides can influence higher brain functions, such as learning and memory, in humans and animals (Mclay et al. 2001). However, there is a paucity of information on bioactive peptides from food-derived products, which may have potential to serve as $\beta$-secretase inhibitors. The objective of this study was to isolate and characterize $\beta$-secretase inhibitory peptides purified from shrimp waste hydrolysates, and to elucidate the active component peptide(s) and the mode of inhibition of $\beta$-secretase.

\section{Methods}

\section{Materials}

Shrimp processing by-products (including shells, heads and tails recovered from hand-peeling of cooked shrimp Pandalopsis dispar) in frozen form were donated by Albion Fisheries Ltd. (Vancouver, BC, Canada). Shrimp wastes hydrolysis was performed under experimental conditions according to Cheung and Li-Chan (2010). Protamex ${ }^{\circ}$ (Bacillus amyloliquefaciens and Bacillus licheniformis, $1.5 \mathrm{AU} / \mathrm{g}$ ), a product from Novozymes North America Inc. (Salem, NC), was donated by Neova Technologies Inc. (Abbotsford, BC, Canada). $\beta$-secretase and MCAEVKMDAEFK-(DNP)- $\mathrm{NH}_{2}$ ( $\beta$-secretase substrate I) was purchased from Sigma Chemical Co. (St. Louis, $\mathrm{MO})$. All other reagents used in this study were reagent grade chemicals.

\section{Preparation of shrimp waste hydrolysates(SWHs)}

SWHs were prepared using Protamex enzyme for hydrolysis of the shrimp waste under varying conditions of water:substrate ratio (1:1, 1:1.5, 1:2 or 1:2.5), percent enzyme $(2,4,6$ or $8 \% \mathrm{w} / \mathrm{w}$ protein contents of shrimp processing by-products) and time of hydrolysis (1, 4, 8 or $24 \mathrm{~h}$ ) (Table 1$)$. The lyophilized hydrolysates were

Table 1 The conditions for hydrolysis of shrimp processing byproducts

\begin{tabular}{llllll}
\hline Sample & \multicolumn{5}{c}{ Hydrolysis conditions } \\
\cline { 2 - 6 } & Protease & W:S & Enzyme(\%) & Time(h) & $\mathrm{pH}$ \\
\hline SWH1 & Protamex & $1.5: 1$ & 4 & 1 & 8.4 \\
SWH4 & Protamex & $2.5: 1$ & 6 & 4 & 8.3 \\
SWH8 & Protamex & $2: 1$ & 2 & 8 & 8.3 \\
SWH24 & Protamex & $1: 1$ & 8 & 24 & 8.0 \\
\hline
\end{tabular}

stored at $-80{ }^{\circ} \mathrm{C}$ until use. The SWHs was provided from Li-Chan's laboratory in UBC, Canada.

\section{Measurement of $\beta$-secretase inhibitory activity}

$\beta$-Secretase inhibitory activity was measured following Johnston et al. (2008), using a commercially available fluorogenic substrate, MCA-EVKMDAEFK-(DNP)$\mathrm{NH}_{2}$. This substrate corresponded to the wild-type APP sequence, derivatised at its $\mathrm{N}$-terminus with a fluorescent 7-methoxycoumarin-4-yl acetyl (MCA) group, and on its $\mathrm{C}$-terminal lysine residue with a 2,4-dinitrophenyl (DNP) group. In the intact peptide the fluorescence of the MCA group was abolished by internal quenching from the DNP group. Upon cleavage by $\beta$-secretase activity the MCA fluorescence could be detected. Assays were performed in 96-well black plates using a Spectrofluorometer (Molecular Devices). $\beta$-secretase and $\beta$-secretase substrate I were incubated in a final volume of $200 \mu \mathrm{l}$ in assay buffer $(50 \mathrm{mM}$ sodium acetate, $\mathrm{pH} 4.5)$. The hydrolysis of $\beta$-secretase substrate I was followed at $37{ }^{\circ} \mathrm{C}$ for $30 \mathrm{~min}$, by measuring the accompanying increase in fluorescence. Readings (excitation $325 \mathrm{~nm}$, emission $393 \mathrm{~nm}$ ) were taken every $60 \mathrm{~s}$. The inhibition ratio was obtained by the following equation: Inhibition $(\%)=[1-\{(\mathrm{S}-\mathrm{S} 0) /$ $(\mathrm{C}-\mathrm{C} 0)\} \times 100]$, where $\mathrm{C}$ is the fluorescence of a control (enzyme, assay buffer, and substrate) after $60 \mathrm{~min}$ of incubation, $\mathrm{CO}$ is the fluorescence of control at zero time, $\mathrm{S}$ is the fluorescence of tested samples (enzyme, sample solution, and substrate) after $60 \mathrm{~min}$ of incubation, and S0 is the fluorescence of the tested sample at zero time. All data are the means of triplicate experiments.

\section{Purification of $\beta$-secretase inhibitory peptide}

The potent fraction as determined from $\beta$-secretase inhibitory activity assay was further purified by size exclusion chromatography on a Sephadex G-25 gel filtration column $(25 \times 750 \mathrm{~mm})$ equilibrated with distilled water. Separated fractions were monitored at $215 \mathrm{~nm}$, collected at a volume of $7.5 \mathrm{ml}$ and measured for $\beta$-secretase inhibitory activity. The most active fraction was then injected into a preparative reversed phase HPLC column (YMC, ODS C18, 10.0 × $250 \mathrm{~mm}, 5 \mu \mathrm{m}$ ) and separated using a linear gradient of acetonitrile $(0-40 \% \mathrm{v} / \mathrm{v})$ containing $0.1 \%$ trifluoroacetic acid (TFA) on an HPLC system (Agilent Technologies, USA). The peak showing potent inhibitory activity was finally purified into a single peptide on a reversed phase HPLC analytical C18 column $(4.6 \times 250 \mathrm{~mm}$, $5 \mu \mathrm{m})$ using a linear gradient of acetonitrile $(0-20 \% \mathrm{v} /$ v) in $0.1 \%$ TFA. 


\section{Amino acid sequence of purified peptide}

To identify molecular weight and amino acid sequence of the purified peptide, all MS/MS experiments were performed on a Q-TOF tandem mass spectrometer (Micromass Co., Manchester, UK) equipped with a nano-ESI source. The peptide solution was desalted using Capcell Pak C18 UG120 V $(4.6 \times 250 \mathrm{~mm}$, $5 \mu \mathrm{m}$, Shiseido, Tokyo, Japan). The purified peptide dissolved in methanol/water $(1: 1, \mathrm{v} / \mathrm{v})$ was infused into the ESI source and molecular weight was determined by doubly charged $(\mathrm{M}+2 \mathrm{H})^{2+}$ state in the mass spectrum. Following molecular weight determination, peptide was automatically selected for fragmentation and sequence information was obtained by tandem MS analysis.

\section{Determination of $\beta$-secretase inhibition pattern}

For the Lineweaver-burk plot, the data were plotted as mean values of $1 / \mathrm{v}$, the inverse of the increase in fluorescence intensity per min ( $\mathrm{min} / \mathrm{DRFU}$ ) of three independent tests with different concentrations of fluorescent substrate. The assay was performed in the presence of purified peptide (final concentration of $0,25,50$ and $100 \mu \mathrm{g} / \mathrm{ml}$ ).

\section{Synthesis of $\beta$-secretase inhibitory peptides}

The peptides were chemically synthesized in the peptide synthesis facility, PepTron Inc. (Daejeon, Korea). The peptides were synthesized using the Fmoc-solid phase method with a peptide synthesizer (PeptrEX-R48, Peptron Inc., Daejeon, Korea). These synthetic peptides were purified by RP-HPLC using a Capcell Pak C18 column (Shiseido, Japan). Elution was performed with a wateracetonitrile linear gradient $(0-80 \%$ of acetonitrile) containing $0.1 \%(\mathrm{v} / \mathrm{v})$ TFA. Elution was monitored at $220 \mathrm{~nm}$ on HPLC instrument (Prominence HPLC, Shimadzu, Tokyo, Japan).

\section{Statistical analysis}

Each experiment was performed at least three times and results were presented as the mean \pm SD. Statistical comparisons of the mean values were performed by analysis of one-way ANOVA (SPSS 12, IBM, IL, Chicago, USA), followed by Duncan's multiple-range test using SPSS (12) software. Differences were considered significant at $p<0.05$.

\section{Results and discussions}

\section{$\beta$-secretase inhibitory activity of SWHs}

$\beta$-secretase inhibitory activity was measured using an assay that we developed and validated using a commercially available fluorogenic substrate. Figure 1a shows the kinetics of $\beta$-secretase inhibitory activity from SWHs and a control. A fluorescent signal (in relative fluorescence units) was found over 0-60 min with hydrolysates (or buffer) at $0.5 \mathrm{mg} / \mathrm{ml}$ and $10 \mathrm{mM} \beta$-secretase substrate I. The fluorescence of $\beta$-secretase incubated in the absence of membrane protein was subtracted at each time point. There appeared to be a linear increase in signal beginning after $5 \mathrm{~min}$ that continued for up to $1 \mathrm{~h}$. Among hydrolysates, SWH24 was particularly potent. As seen in Fig. $1 \mathrm{~b}$, the lowest $\mathrm{IC}_{50}$ value was exhibited by SWH24 at $0.54 \mathrm{mg} / \mathrm{ml}$. These discrepancies may be attributed to differences in substrate specificity and conditions for optimal activity of the enzyme preparations, as well as to differing peptide sequences and structural factors affecting reactivity of the protein substrates. The findings underline the importance of selecting the appropriate combination of experimental conditions to release bioactive peptide sequences (Cheung and Li-chan 2010). Protamex hydrolysates has previously been reported to be effective in various bioactivity such as producing potent ACE inhibitory peptides from marine source (He et al. 2007).
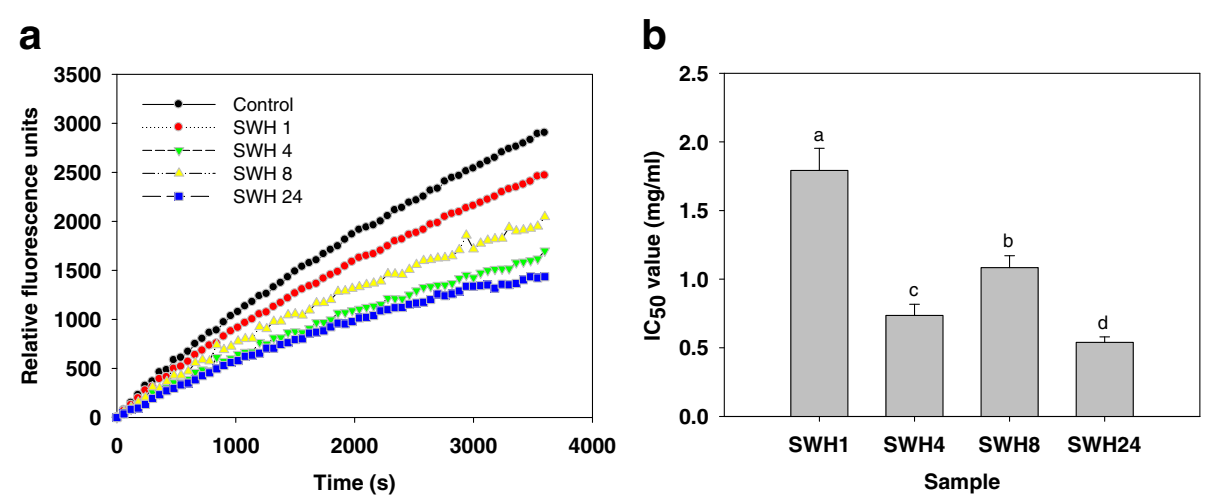

Fig. 1 Effect of shrimp waste hydrolysates (SWHs) on the inhibitory activity of $\beta$-secretase. a Relative fluorescence unit of SWHs under $10 \mathrm{mM} \beta$-secretase substrate I was incubated with hydrolysates $(0.5 \mathrm{mg} / \mathrm{ml})$ or buffer (control). b $\mathrm{IC}_{50}$ value $(\mathrm{mg} / \mathrm{ml})$ of SWHs. Letters indicate significantly $(P<0.05)$ different averages (ANOVA, Duncan's test) 


\section{Purification of $\beta$-secretase inhibitory peptide}

The use of Sephadex G-25 chromatography led to a fraction with greatly improved $\beta$-secretase inhibitory activity (Fig. 2-I). First, fraction D from SWH24 had the highest $\beta$-secretase inhibitory activity, with an $\mathrm{IC}_{50}$ value of $0.19 \mathrm{mg} / \mathrm{ml}$. The lyophilized fraction D was further separated into eight sub-fractions by HPLC on an ODS column with a linear gradient of acetonitrile $(0$ $50 \%$ ) (Fig. 2-II). Finally, the purified fraction B2 was found to have the highest $\beta$-secretase inhibitory activity (Fig. 2-III). The active fraction B2 was subjected to rechromatography on the HPLC column using a isocratic elution with $22.5 \%$ acetonitrile for $30 \mathrm{~min}$, at a flow rate of $1.0 \mathrm{ml} / \mathrm{min}$ (Fig. $2-\mathrm{IV}$ ). The $\mathrm{IC}_{50}$ value of this purified peptide was $58.31 \mu \mathrm{g} / \mathrm{ml}$. The $\beta$-secretase inhibitory activity of purified peptide was increased by 10.52 -fold compared to the SWH24 $(0.54 \mathrm{mg} / \mathrm{ml})$, using the four step purification procedure.

\section{Identification of $\beta$-secretase inhibitory peptide}

The amino acid sequence of the purified $\beta$-secretase inhibitory peptide were identified using MS/MS. For SWH24, the sequence was found to be Asp-Val-LeuPhe-His $(629 \mathrm{Da})$ for fraction $\mathrm{B} 2$, with an $\mathrm{IC}_{50}$ value of $92.70 \mu \mathrm{M}$ (Fig. 3). The amino acid sequence of this peptide is critical in its $\beta$-secretase inhibitory activity.
(I)
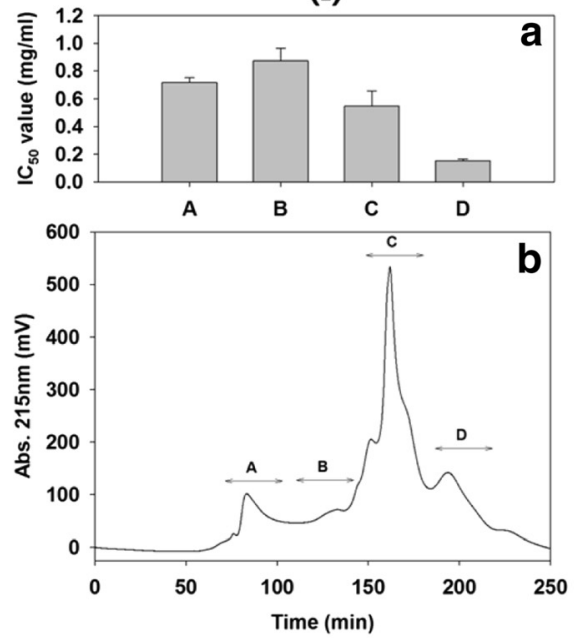

(III)
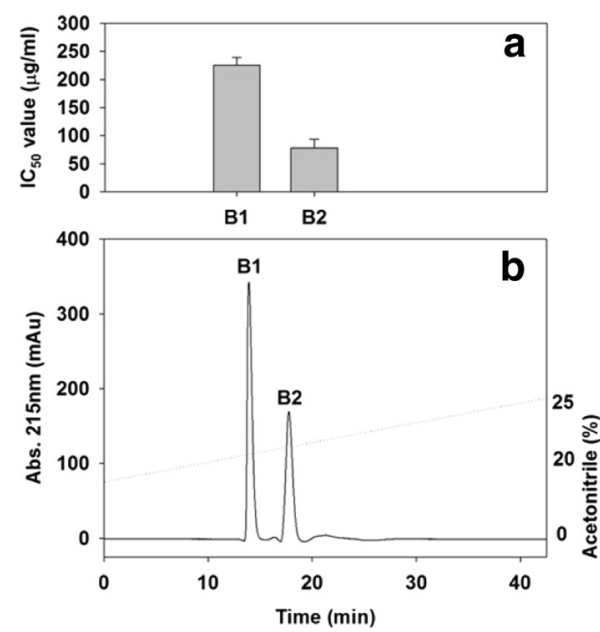

(II)
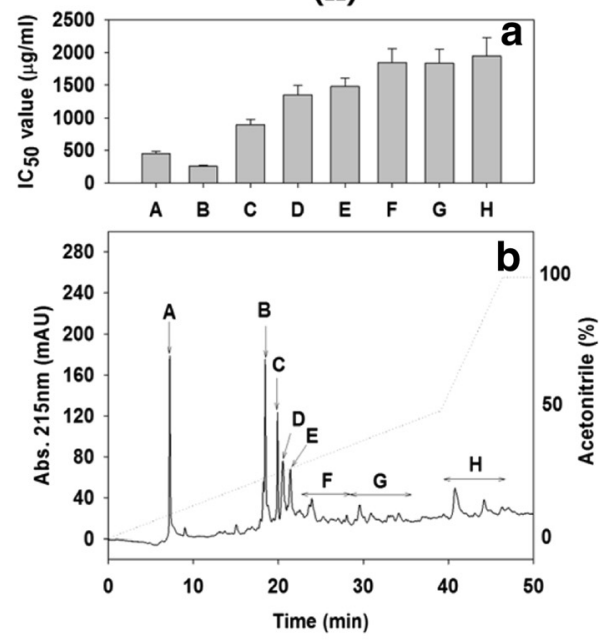

(IV)
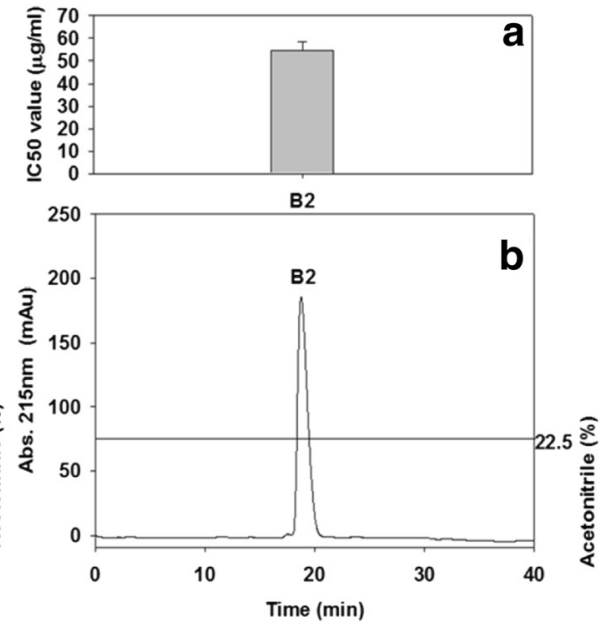

Fig. 2 Purification steps of $\beta$-secretase inhibitory peptide from SWH24 by Sephadex G-25 column chromatography and HPLC. I Sephadex G-25 Gel filtration chromatogram of hydrolysates prepared with SWH24 (b, lower layer). Separation was performed with $1.5 \mathrm{ml} / \mathrm{min}$ and collected at a fraction volume of $7.5 \mathrm{ml}$. The fractions isolated by Sephadex G-25 Gel column were separated (A D and $\beta$-secretase activity determined as upper panel (a). II,III,IV HPLC chromatogram of potent $\beta$-secretase inhibitory activity of separated fraction from previous step. Separation was performed with linear gradient of acetonitrile at a flow rate of $1.0 \mathrm{ml} / \mathrm{min}$ and Grom-sil 120 ODS -5 ST column $(5 \mu \mathrm{m}, 10 \times 250 \mathrm{~mm})$. Elution was monitored at $215 \mathrm{~nm}$ (b, lower layer). The fractions showing $\beta$-secretase inhibitory activity were determinded $\mathrm{IC}$ 50 $(\mathrm{mg} / \mathrm{ml})$ as shown in upper layer (a) 


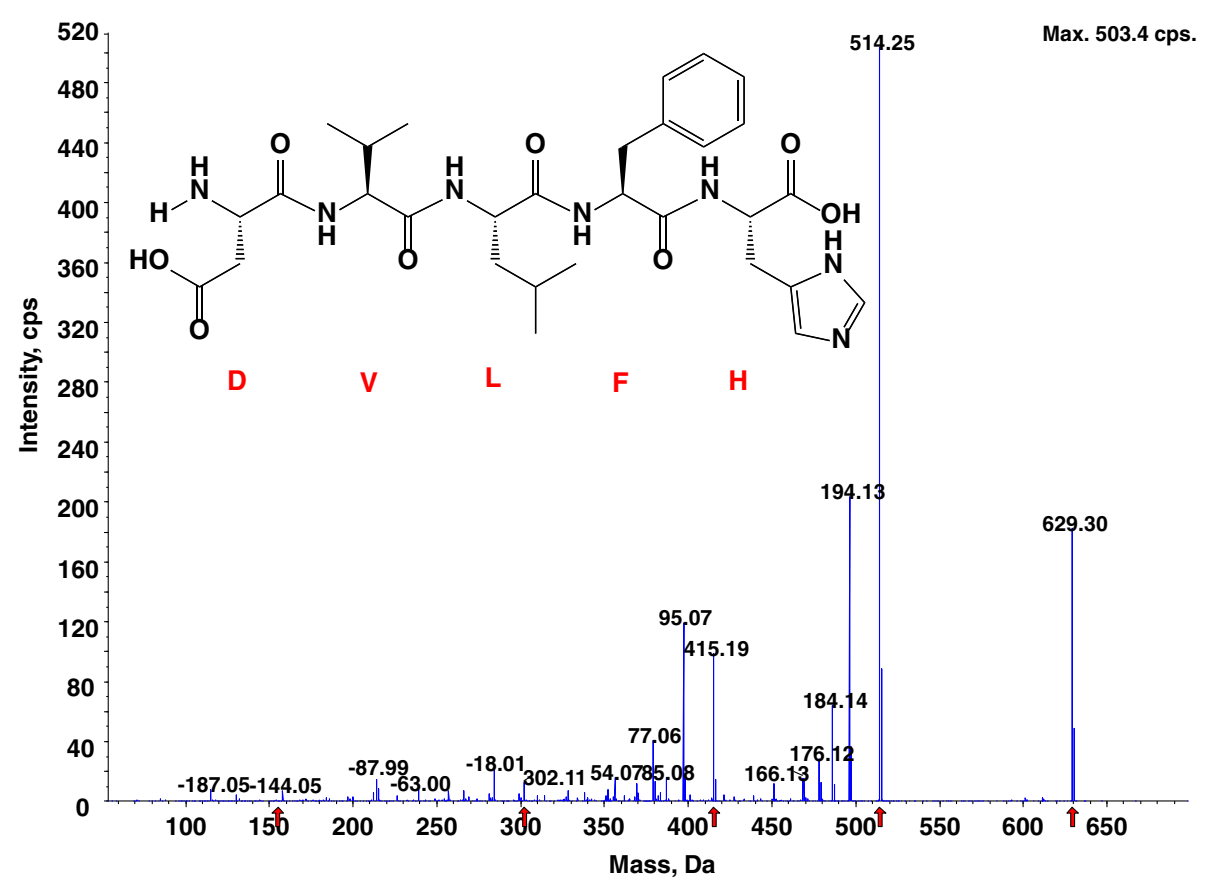

Fig. 3 Identification of molecular weight and amino acid sequence of the purified peptide from SWH24 by HPLC. MS/MS experiments were performed on a Q-TOF tandem mass spectrometer equipped with a nano-ESI source

Kimura et al. (2010) investigated the synthetic $\beta$-secretase inhibitor, $\mathrm{KMI}-370\left(\mathrm{IC}_{50}\right.$ value $\left.=3.4 \mathrm{nM}\right)$, whose activity was greater than that of the purified peptide $\left(\mathrm{IC}_{50}\right.$ value $=92.70 \mu \mathrm{M})$. Because its molecular weight was much smaller than those of the others, it was considered suitable for absorption in the intestine. Lee et al. (2007) found that the amino acid sequence of a purified $\beta$-secretase inhibitor peptide from Saccharomyces cerevisiae was Gly-ProLeu-Gly-Pro-Ile-Gly-Ser with N-terminal sequence analysis. The molecular weight of the purified $\beta$-secretase inhibitor was estimated to be $697 \mathrm{Da}$ by LC-MS, and its $\beta$-secretase inhibitory activity $\mathrm{IC}_{50}$ value was $2.59 \mu \mathrm{M}$. In spite of having the highest inhibition efficiency, they reported that this octapeptide needs a reduced molecular weight to overcome metabolic instability. The purified $\beta-$ secretase inhibitory peptide acted competitively with a substrate according to the Lineweaver-burk plots (Fig. 4). This strongly suggests that the purified peptide might have an affinity for the active site of an enzyme where the substrate also binds; the substrate and inhibitor compete for access to the enzyme's active site. Derivatives of these peptides are expected to be useful in the prevention of $\mathrm{AD}$ through the development of novel peptidic inhibitors. Availability of protein/ligand structures has opened up the possibility of structure-based design of $\beta$-secretase inhibitors. Prototypical aspartic acid protease inhibitors are peptides of high molecular weight, and contain a secondary alcohol that acts as a transition-state mimetic via the formation of hydrogen bonds with the catalytic aspartic acid groups (Bursavich and Rich 2002). Potent transition state-mimetic $\beta$-secretase inhibitors have been reported by several groups, and the area has been reviewed recently (Hong et al. 2005). OM99-2, a synthesized peptidyl inhibitor of human brain $\beta$-secretase (Hong et al. 2005), was utilized to learn the interactions of the $\beta$-secretase active site. The inhibitor was bound in the substrate-binding cleft located between the

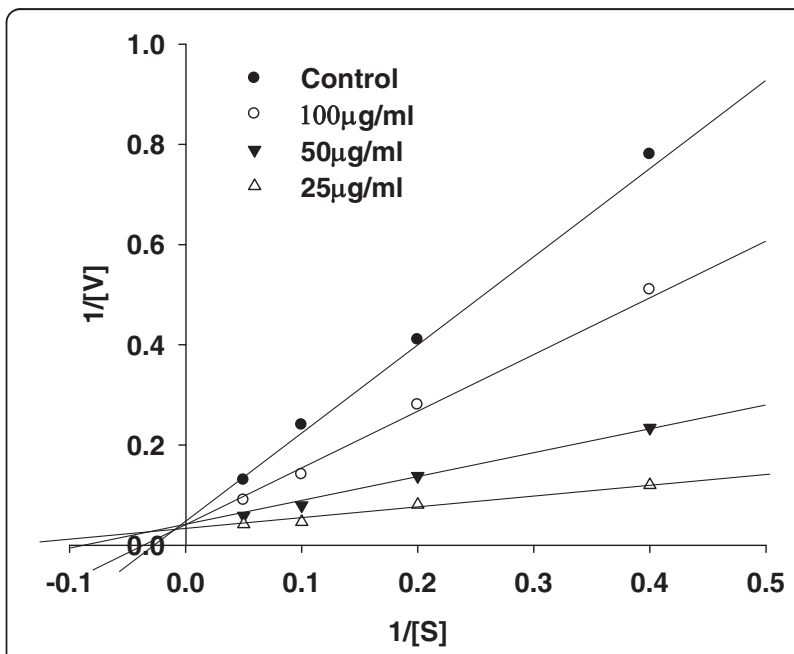

Fig. 4 Lineweaver-burk plots for determining inhibition pattern of the purified inhibitor against $\beta$-secretase. The intersection of the three lines on the vertical axis signified that the purified $\beta$-secretase inhibitor was a competitive inhibitor 
$\mathrm{N}-$ and $\mathrm{C}$-terminal lobes. Six of the eight OM99-2 residues $\left(\mathrm{P} 4 \sim \mathrm{P}^{\prime} 2\right)$ are bound in the active site of $\beta$ secretase in an extended structure and their respective binding sites $\left(S 4 \sim S^{\prime} 2\right)$ are well-designated by atomic contacts with the inhibitor side.

\section{$\beta$-secretase inhibitory activity of synthetic peptides}

The peptide Asp-Val-Leu-Phe-His was purified from SWH24. Based on it, five synthetic peptides were prepared in order to study their $\beta$-secretase inhibitory activity relative to their amino acid sequences. They were further purified using a reversed-phase HPLC. The resulting $\mathrm{IC}_{50}$ values of the synthetic peptides are shown in Table 2. Among the synthetic peptides, the $\mathrm{IC}_{50}$ value of Leu-Phe-His was $34.11 \mu \mathrm{M}$. Moreover, the $\mathrm{IC}_{50}$ values of the synthetic peptides were improved over the original peptide isolated from SWH24 (AspVal-Leu-Phe-His, $\left.\mathrm{IC}_{50}, 92.70 \mu \mathrm{M}\right)$. Synthesized LeuPhe-His acted competitively according to the Lineweaver-Burk plot (data not shown). In both peptides (AspVal-Leu-Phe-His and Leu-Phe-His), leucine is likely to be the important residue for $\beta$-secretase inhibition. In the $\beta$-secretase inhibitory mechanism, leucine plays an important role in the Swedish mutant APP, which has a mutation at the P2-P1 positions from Lys-Met to Asn-Leu. Generally, $\beta$-secretase has eight (P1 P4 and P1' $\left.\sim \mathrm{P} 4{ }^{\prime}\right)$ residues that are important in the catalytic domain, determined by its crystal structure. Inhibitory activities against $\beta$-secretase when the P2 position was changed to several other amino acids have been described (Hong et al. 2005). In the case of hydrophilic amino acids (Asp, Asn, Glu, and Gln) in the P2 position, the inhibitory activities were weak ( $\beta$-secretase inhibitory activity of 25-36\%). However, with hydrophobic amino acids like leucine in the P2 position, significant inhibitory activity was present $(\beta$-secretase inhibitory activity of $>90 \%$ ). These results suggested that a hydrophobic interaction at the P2 site of $\beta$-secretase was more effective than a hydrophilic one, in spite of the hydrophilic property of the P2 site. Leucine was employed as the P2 moiety for the synthetic $\beta$-secretase inhibitor. The isolated and synthesized peptides may not be directly considered as potential drug candidates, since they have relatively groups. However, this is the first

Table $2 \beta$-secretase inhibitory activity of synthesized peptides

\begin{tabular}{lr}
\hline Synthesized Peptide & $I C_{50}$ value $(\mu \mathrm{M})$ \\
\hline Asp-Val-Leu-Phe-His & $101.54 \pm 11.54^{\mathrm{a}}$ \\
Asp-Val-Leu & $41.93 \pm 4.14^{\mathrm{c}}$ \\
Asp-Val & $67.46 \pm 7.83^{\mathrm{b}}$ \\
Leu-Phe-His & $34.11 \pm 9.01^{\mathrm{c}}$ \\
Phe-His & $104.76 \pm 8.67^{\mathrm{a}}$ \\
\hline
\end{tabular}

a-c, Letters indicate significantly $(P<0.05)$ different averages (ANOVA, Duncan's test) report on the $\beta$-secretase inhibiting activity of marine organisms. These isolated and synthesized peptides from SWH24 could be useful in the study of the mechanisms of Alzheimer's disease.

\section{Conclusion}

In conclusion, the hydrolysate of shrimp waste protein generated by proteinases treatment followed by consecutive purification of gel filtration and reversed-phase HPLC resulted in a novel $\beta$-secretase inhibitory peptide of DVLFH. The purified peptide acted as a competitive inhibitor against $\beta$-secretase with an $\mathrm{IC}_{50}$ value of $92.70 \mu \mathrm{M}$ and molecular weight of $629 \mathrm{Da}$. We were synthesized novel $\beta$-secretase inhibitory peptide base on amino acid sequences of DVLFH. Among the synthesized peptides, LFH had higher $\beta$-secretase inhibitory activity the other synthesized peptides. Our present results proposed that the $\beta$-secretase inhibitory peptides derived shrimp waste protein could be used as nutraceutical ingredients and alzheimer's disease medicine. The manufacturing of hydrolysates and peptides loaded with bioactive peptide-rich protein from shrimp by-products could be a new possibility for functional foods.

\section{Competing interests \\ The authors declare that they have no competing interests.}

\section{Authors' contributions}

HGB and ECYL conceived and designed the study. IWYC prepared the samples and assisted with data collection. HGB performed the experiments, analyzed the data, and drafted the manuscript. All authors read and approved the final manuscript.

\section{Acknowledgement}

This study was supported by Gangneung-Wonju National University.

\section{Author details}

${ }^{1}$ Food, Nutrition \& Health Program, Faculty of Land \& Food Systems, The University of British Columbia, 2205 East Mall, Vancouver, BC V6T 1Z4,

Canada. ${ }^{2}$ Department of Marine Biotechnology, Gangneung-Wonju National University, Gangneung 210-702, Republic of Korea.

Received: 4 January 2016 Accepted: 28 January 2016

Published online: 25 April 2016

\section{References}

Bursavich MG, Rich DH. Designing non-peptide peptidomimetics in the 21st century: inhibitors targeting conformational ensembles. J Med Chem. 2002; 45:541-58.

Byun HG, Kim YT, Park PJ, Lin X, Kim SK. Chitooligosaccharides as a novel $\beta$ secretase inhibitor. Carbohyd Polym. 2005;61:198-202.

Chen J, Suetsuna K, Yamauchi F. Isolation and characterization of immunostimulative peptides from soybean. J Nutr Biochem. 1995;6:310-3.

Cheung IWY, Li-Chan ECY. Angiotensin-1-converting enzyme inhibitory activity and bitterness of enzymatically-produced hydrolysates of shrimp (Pandalopsis dispar) processing byproducts investigated by Taguchi design. Food Chem. 2010;122:1003-12.

Cheung LKY, Cheung IWY, Li-Chan ECY. Effects of production factors and eggbearing period on the antioxidant activity of enzymatic hydrolysates from shrimp (Pandalopsis dispar) processing byproducts. J Agric Food Chem. 2012; 60:6823-31.

Citron M. Beta-secretase inhibition for the treatment of Alzheimer's diseasepromise and challenge. Trends Pharmacol Sci. 2004;25:92-7. 
Cumming JN, Iserloh U, Kennedy ME. Design and development of $\beta$-secretase inhibitors. Curr Opin Drug Disc Devel. 2004;7:536-56.

Dey SS, Dora KC. Antioxidative activity of protein hydrolysate produced by alcalase hydrolysis from shrimp waste (Penaeus monodon and Penaeus indicus). J Food Sci Tech. 2014;51:449-57.

He HL, Chen XL, Wu H, Sun CY, Zhang ZY, Zhou BC. High throughput and rapid screening of marine protein hydrolysates enriched in peptides with angiotensin-I-converting enzyme inhibitory activity by capillary electrophoresis. Bioresource Technol. 2007;98:3499-505.

Hong L, He X, Huang X, Chang W, Tang J. Structural features of human memapsin 2 (beta-secretase) and their biological and pathological implications. Acta Biochim Biophys Sin. 2005;36:787-92.

Johnston JA, Liu WW, Coulson DTR, Todd S, Murphy S, Brennan S. Platelet $\beta$-secretase activity is increased in Alzheimer' disease. Neurobiol Aging. 2008;29:661-8.

Kimura R, Devi L, Ohno M. Partial reduction of BACE1 improves synaptic plasticity, recent and remote memories in Alzheimer's disease transgenic mice. J Neurochem. 2010;113:248-61.

Kwak HM, Jeon SY, Song BH, Kim JG, Lee JM, Lee KB, Jeong HH, Hur J M, Kang $\mathrm{YH}$, Song KS. $\beta$-Secretase (BACE1) inhibitors from pomegranate (Punica granatum) husk. Arch Pharm Res. 2005;28:1328-32.

Lee DH, Lee DH, Lee JS. Characterization of a new antidementia $\beta$-secretase inhibitory peptide from Saccharomyces cerevisiae. Enzyme Microb Tech. 2007; 42:83-8.

Lee HJ, Seong YH, Bae KH, Kwon SH, Kwak HM, Nho SK, Kim KA, Hur JM, Lee KB, Kang YH, Song KS. $\beta$-secretase (BACE1) inhibitors from Sanguisorbae radix. Arch Pharm Res. 2011;28:799-803.

McLay RN, Pan W, Kastin AJ. Effects of peptides on animal and human behavior. Peptides. 2001;22:2181-255.

Mendis E, Rajapakse N, Kim SK. Antioxidant properties of a radicals scavenging peptide purified from enzymatically prepared fish skin gelatin hydrolysate. J Agr Food Chem. 2005;53:581-7.

Park IH, Jeon SY, Lee HJ, Kim SI, Song KS. A $\beta$-secretase (BACE1) inhibitor hispidinfrom the mycelial cultures of Phellinuslinteus. Planta Med. 2004;70:143-6.

Stachel SJ, Coburn CA, Steele TG, Jones KG, Loutzenhiser EF, Gregro AR. Structure-based design of potent and selective cellpermeable inhibitors of human $\beta$-secretase (BACE-1). J ACS Med Chem Lett. 2004;47:6447-50.

Turner RT, Koelsch G, Hong L, Castanheira P, Ermolieff J, Ghosh AK. Subsite specificity of memapsin 2 ( $\beta$-secretase): implications for inhibitor design. Biochem. 2001;40:10001-6.

World Health Organization and Alzheimer's Disease International. Dementia: a public health priority. World Health Organization, 2012.

\section{Submit your next manuscript to BioMed Central and we will help you at every step:}

- We accept pre-submission inquiries

- Our selector tool helps you to find the most relevant journal

- We provide round the clock customer support

- Convenient online submission

- Thorough peer review

- Inclusion in PubMed and all major indexing services

- Maximum visibility for your research

Submit your manuscript at www.biomedcentral.com/submit

Biomed Central 